\title{
SERIES EDITORS’ FOREWORD
}

The Women, Theatre and Performance series was born out of a desire to bring together research on the many aspects of women's contributions to theatre and performance histories. Historically the 'Second Wave' women's movement in the 1980 s produced research on women in the theatre industry, and their work as playwrights, performers, designers, theatre makers and consumers of theatre and performance. Feminist performance analysis and women's theatre history has now become an established part of performance practice and theatre studies at both a university and a more popular level, although work made by women frequently remains marginal to many educational curricula and within the mainstream repertoire.

In the 1990s, the journal Women and Theatre Occasional Papers, from which this series arose, placed an emphasis on history and historiography. Founding series editors Maggie B. Gale and Viv Gardner were concerned to open out women's theatre histories beyond those considered within feminist praxis. Work made by women seen as more mainstream or more commercial was explored alongside more innovative and politically oriented practices. This came from a desire to find a consistent outlet for the retrieval project of women's theatre and performance histories. The emphasis on history does not preclude engagement with contemporary practice, as our edited volumes evidence. Women, Theatre and Performance seeks to make research and debate on women's performance practices available on a more than 'occasional' basis and has so far included edited volumes and single themed monographs as well as reprints of performance texts by women, all of which share in common the consideration of women's theatre and performance as part of a wider nexus of theatre histories and of social and cultural practices.

Maggie B. Gale and Kate Dorney, The University of Manchester

Editorial Board: Gilli Bush-Bailey, Emeritus Professor of Women's Theatre History at the Royal Central School for Speech and Drama, London; Viv Gardner, Emeritus Professor of Drama, the University of Manchester. 